\title{
THE EFFECT OF LANGUAGE LEARNING STRATEGY AND TECHNOLOGY TOWARD STUDENTS'WRITING SKILLS
}

\author{
Asfar Arif Nurharjanto and Agus Widyantoro \\ Yogyakarta State University, Yogyakarta, Indonesia \\ email: asfararif.2017@student.uny.ac.id
}

\begin{abstract}
This study aimed to find relationship between students' use of language learning strategies and technology to their writing performance. This study was quantitative research. The data were gathered through a survey employing a questionnaire and writing test. The respondents were 459 students grade XI from six high schools in their fisrt semester. The study employed Strategy Inventory Language Learning questionnaire developed by Oxford. The instruments were through experts to ensure the validity and reliability. Multiple Regression was used to look for the relationship between the two independent variables with the dependent variable. Findings suggest that both language learning strategies and students' technology use significantly influence the students' writing performance. Moreover, language learning strategies as well as technology use, when analyzed separately, positively influence students' writing performance. The findings confirm that including and promoting both language learning strategies and technology use are able to improve students' writing performance in the classroom.
\end{abstract}

Keywords: language learning strategy, tecnology use, writing skills

\section{INTRODUCTION}

Language learning strategies (LLS) have attracted great interest of many researchers in the language teaching area for decades. They are known as a factor influencing the success of learning a language. Students who are able to use effective language learning strategies in their learning are likely to be successful (Oxford, 2008). Having abilities to employ language learning strategies helps language learners to enhance their learning and acquire the form and function which they need in order to communicate effectively in a second or foreign language (Zeynali, 2012). It helps them to take control of their mental, behavior, social to support their learning. Students who use a strategy usually become more efficient and more confident as the strategy acts as a tool for active, self-directed involvement. The more strategies that students use are highly related to the success of their proficiency in learning a language (Ardasheva \& Tretter, 2013).

Language learning strategy is usually defined as an action or behavior done by learners to help them acquire, learn, perform, or retrieve knowledge so as to make learning more effective, enjoyable, and faster (Oxford, 2016). It also enables students to be more autonomous and confident. Thus, language learning strategies in the end leads to higher achievement if it is implemented appropriately in the classroom. Many studies prove that learners who employ strategies tend to get better achievements. A study suggests that the students' awareness of implementing strategies leads to positive contributions in their speaking skills (Nakatani, 2010). After training students with strategy, their speaking skills improve 
significantly. These findings prove that language learning strategies contribute to students' achievement (De Silva, 2015).

In addition, some students might not recognize and are not able to use language learning strategies at all. Meanwhile, some students who recognize language learning strategies often use them ineffectively. In turn, some researchers believe that language learning strategies play little to no part in students' language development ( $\mathrm{Su}, 2018$ ). Language learning across the world had found that South African learners do not know that language learning strategies exist and it is quite contrary to the rest of the world who has been trying to develop language learning strategies for decades. This fact cannot simply conclude that the African students do not use learning strategies at all but they may not be aware of their existence yet. Despite all the debates regarding the effect of learning strategies on students' performance in the classroom, I argue that language learning strategies are still a crucial factor for determining students' success as strategies influence students' performance (Oxford et al., 2014).

Technology now has become a large part of education that also shapes language teaching learning in the classroom. For example, through the internet, students gain access to authentic L2 material, to a virtual immersion classroom through a video call and to a web where they can express their voice, self-image and legitimize their goal (Blake, 2013). Technology can be beneficial for students as it eases students' work like composing work, finding material, having communication with peers or teachers, and even creating native-like environments. In addition, using technology inside the classroom can motivate students. It is pointed out that using technology in the classroom fostered the development of attitudes. These potentials have great opportunities to enhance the teaching and learning process both inside and outside of the classroom (Drigas \& Charami, 2014).

Technology creates opportunities for students to actively involve and to be treated equally in language learning activities. Thus, teachers need to be able to implement it in the classroom (Erben, Ban, \& Castaneda, 2009). Students' motivational beliefs and their choices of learning strategies affect their preferences on the kind of classrooms they are comfortable to be in. Teachers aimed to find the students' motivational beliefs and choices of learning strategies when the online learning environment is lacking (Clayton, Blumberg, $\&$ Auld, 2010). Learning strategies are, therefore, associate to self-regulated learning which covers both metacognitive and cognitive strategies. They found that learners tended to choose traditional learning when they could not fully engage in an online course as the traditional course offered more instructional strategies usage and accommodate learning styles. Therefore, it implies that the availability of technology would affect the students' use of strategies. However, students' uses of technology are influenced by their competences and affordances of technology around them (Egbert, 2018). In turn, students do not share the same ability to use technology even if they have the same devices or available technology between them. Further, sometimes students know that particular technology can be used to support their learning but they decide not to use it for the sake of learning (Bikowski \& Casal, 2018). In addition, technology also comes with some consideration despite its ability to enhance learning. Both students and teachers have to make use of it effectively. It demands them to learn how to use the technology first before they want to implement it in the teaching and learning 
process. It has been pointed out that learners should have been given opportunities to develop and apply their ability to use ICT by utilizing ICT to boost their learning and to seek out various learning sources (Adams \& Brindley, 2007).

Although technology comes along with its opportunities to enhance learning, technology also comes with challenges. Even if it is widely spread among schools, students or teachers, technology might not reach all students due to, for example, poverty in which students could not afford a smartphone, a computer device, or even internet access. Students should have a positive value of technology toward learning, experiences in using the devices, familiarity, and self-efficacy as all these factors influence the successful use of technology in classrooms (Rahimi \& Katal, 2012). Moreover, even though they are familiar with it, sometimes the teacher needs to introduce and provide students with the new technology. The more important thing is how the students can make use of technology to enhance their learning. Sometimes, students are able to use technology but to make it able to enhance the teaching learning is still a challenge and it needs the teacher to introduce ways of thinking and strategies to students. Therefore, one student to other students might use technology differently as the students may face those challenges.

Previous research has investigated the underlying relationship between technology use in the classroom with the learning strategies (Rahimi \& Katal, 2012; Saks \& Leijen, 2014; de Andrés Martinez, 2012). Studies showed how distance learning or technology-enhanced learning affected students' use of metacognition strategies. He found that the students' metacognition skills improved along with the use of reflection and learning from their level of awareness. In the same idea, they found out the use of technology in the classroom activates students' learning strategies especially cognitive strategies. They believed technology could enhance metacognitive strategies and self-regulation. However, those studies did not portray possible learning strategies the students might use other strategies aside from the metacognitive strategy. Thus, this current study explored the effect of the other language learning strategies and the use of technology to support students' writing skills.

Learners in the traditional classroom may not have as many opportunities as their counterparts (Oxford \& Lin, 2011). Technology offers many advantages to language learning learners. However, to optimally utilize technology, language learners need to have and to employ appropriate learning strategies. Language learners in Indonesia, despite their affordances of technology around them, still might not purposefully use technology to support their language learning. Thus, it is crucial to explore how language learners utilize technology in their surroundings for their learning.

\section{METHOD}

This study was quantitative. The quantitative data were gathered through a survey employing a questionnaire. The survey was suitable for this research as it aimed to gather numerous participants' responses and to generalize the data. Three types of data were gathered for this study such as students' language learning strategies, students' use of technology and students' writing ability. As it sought for relations between the data, the students' language learning strategies and use of technology were the independent variables while the students' writing abilities were the 
dependent variables. Three instruments were used to gather each data and, after that, the data were statistically inferred. The research was conducted in six senior high schools in the Special Territory of Yogyakarta.

The questionnaire employed to get the quantitative data was in the form of students' responses. Meanwhile, the test was used to take students' scores on writing. Different questionnaires were used for each variable. For the questionnaire for language learning strategies, the Likert Scale model and the items within the questionnaire were developed and constructed based on Strategy Inventory Language Learning (SILL).

SILL version 7 (Oxford, 1993) was used to assess students' language learning strategies. The SILL covered three types of learning strategies: metacognitive, cognitive and affective. The SILL, was then adapted to be 23 items for the questionnaire with an answer on a 4-point Likert Scale ranging from 1 (never true of me) to 4 (always true of me). As for the students' technology use, I developed the questionnaire items based on the literature review. The students' use of technology questionnaire was designed based on the TESOL technology standard framework (Hafner, 2013). TESOL technology standard framework was chosen due to its capabilities to provide sets of standards that draw students' technological knowledge and skills, a pattern of technology use and to provide course evaluation The quantitative data were analyzed by means of the SPSS sotfware. For the writing score, two interraters were employed. The first was the researcher himself and the other was the researcher's colleague. Students' writing scores were statistically and descriptively calculated. Then, the scores were included in the data from the language learning and technology questionnaire. Those data were analyzed to find out correlational statistics to yield a correlation value.

The students' language learning strategies were measured using a questionnaire based on Oxford's Strategy Inventory for Language Learning. It was adapted to suit students' conditions such as their first language and the questionnaire format. It consisted of 23 items with Likert scale choices starting from strongly disagree (1) to strongly agree (5). It was given to the students before the writing test because it did not need as much time as the writing test. The questionnaire's responses were submitted immediately after the students completed theirs. After all the students' responses were submitted, the researcher began to input and calculate the responses.

This study employed two regression techniques to find out the relationship between Language Learning Strategies, Technology' Use, and with Writing. Multiple Regression was used to look for the relationship between the two independent variables with the dependent variable. Table 1 indicates correlations between Language Learning Strategies (LLS) and Technology use to Writing Skills. The number shows that both LLS with $r=.282, \mathrm{Sig} .=.000$ and Technology use with $r=.224$, Sig. $=$ .000 significantly statistically correlate with Writing Skills.

\section{FINDINGS AND DISCUSSION}

Descriptive analysis was employed in this study to present the research findings in the form of descriptive statistic analysis. This analysis provides a hypothesis testing as a preliminary step in decision making and shows all the variables' Minimum Score, Maximum Score, Mean, Median, Modus and Standard deviation which are packed into tables. In doing so, the Likert Scale from 1 to 4 was employed. The data is presented in Table 1. 
In gathering data for the writing skills, a writing test was employed. The instrument was a writing test that was constructed based on the students' current course in their first semester. The test item was an open-ended essay with predetermined topics. Students were asked to develop an essay based on the topic provided by the researcher within the given time. The topics, National Exam and The Use of Plastic Bag were chosen as the researcher thought that they were familiar topics for them.

After the students were given the test, their writings were collected and assessed by researchers. Here, the researcher employed a collaborator to assess the students'writing test to determine inter-rater reliability. A Writing Assessing rubric was also used to help the researcher determine their score.
The collaborator involved in assessing the students' scores was also an English teacher who was not originated from the school where the data were taken. It was done to make sure that the assessment was valid. After the scores from the researcher and collaborator were collected, a statistical analysis of interrater reliability was conducted. The result of the analysis is described in Table 2 .

Table 2 shows that the students' writing score is mostly between 61-80 intervals with a total of 246 students. Meanwhile, there are 184 students whose scores are between 41-60, 26 students in 81-100, and 2 students are in the 21-40 score interval. This distribution shows that most students are good enough or fairly good at writing. There are just a few of them who are really excellent or so poor in writing.

Table 1

Descriptive Statistic of Students' LLS, Technology Use, and Writing Skills

\begin{tabular}{lccc}
\hline \multicolumn{1}{c}{$\begin{array}{c}\text { Descriptive } \\
\text { Analysis }\end{array}$} & $\begin{array}{c}\text { Language Learning } \\
\text { Strategies (X1) }\end{array}$ & $\begin{array}{c}\text { Technology Use } \\
(\mathrm{X} 2)\end{array}$ & $\begin{array}{c}\text { Writing Skills } \\
(\mathrm{Y})\end{array}$ \\
\hline Respondent & 452 & 452 & 452 \\
Minimum & 59.00 & 30.00 & 40.00 \\
Maximum & 235.00 & 92.00 & 93.00 \\
Mean & 151.4137 & 59.9845 & 63.8142 \\
Median & 152.0000 & 60.0000 & 63.0000 \\
Modus & 169.00 & $60.00(\mathrm{a})$ & 58.00 \\
Std. Deviation & 23.10526 & 10.00985 & 8.95968 \\
Variance & 533.853 & 100.197 & 80.276 \\
\hline
\end{tabular}

Table 2

Students' Writing Scores Distribution

\begin{tabular}{clccc}
\hline No & Categories & Interval & Total (f) & Percentage (\%) \\
\hline 1 & Excellent & $81-100$ & 26 & 4.4 \\
2 & Good & $61-80$ & 246 & 54.4 \\
3 & Fair & $41-60$ & 184 & 40.7 \\
4 & Poor & $21-40$ & 2 & 0.4 \\
5 & Very Poor & $0-20$ & 0 & 0.0 \\
\hline \multicolumn{2}{r}{ Total } & 452 & 100 \\
\hline
\end{tabular}


The calculation of students' Language Learning Strategies yieldeds a maximum score of 235 , minimum score 59 , mean 151.4137 , median 152 , modus 169 , variance 533.853, and standard deviation 23.1052.

Table 3 indicates that 294 students, $65 \%$ of them, are into the fair category of language learning strategies use. They are no either good or bad strategies users. It means that the students might already use some categories to support their learning but they are not efficient enough in using those strategies. Meanwhile, the students who belong to the good categories are $19.5 \%$ and $0.2 \%$ for the very good category which is higher than the total number of students in the lower categories, $13.9 \%$ for the poor category, and $1.3 \%$ for the very poor category. It indicates that more students are able to use language learning strategies compared to the students who use strategies poorly. However, the number of students who excellently employ strategies is only $0.2 \%$ which is less than those of very poor category students, $1.3 \%$.

Students' technology use was measured using the questionnaire. There were 23 items for the questions and the students were provided with Likert Scale answers such as strongly disagree, disagree, agree, and strongly agree. The questionnaires were distributed after the students completed the language learning strategies questionnaire.
Before each questionnaire, the researcher gave them an explanation about the purpose of the research as well as the item they should complete. After the students found that the explanation was clear, the questionnaire was distributed to them. Lastly, after they had done with the questionnaire, they submitted them to the researcher. The questionnaire's responses were then calculated to look for the initial score distribution. This was done by classifying their responses into some categories. The calculation of the students' technology use yielded the highest score 92, minimum score 30 , mean score 59.9845, median 60, modus 60, variance 100.197 and standard deviation 10.00985. From these numbers, the following formula was used to determine the interval.

Table 4 indicates that the majority of the scores are 272 between 52-66 interval, 89 students between $67-80,70$ students between 28-51, 13 students between 81-92, 8 students between 23-37. From these numbers, it can be seen that most of the students are in the fair category which indicates that they are not that sophisticatedly use technology in their surroundings. The table above shows that $60.2 \%$ of the students belong to the fair category which indicates that most of the students are able to use technology although they do not fully utilize technology. The

Table 3

Students' Language Learning Strategies

\begin{tabular}{rlccc}
\hline No & Categories & Interval & Total (f) & Percentage (\%) \\
\hline 1 & Very Good & $211-250$ & 1 & 0.2 \\
2 & Good & $171-210$ & 88 & 19.5 \\
3 & Fair & $131-170$ & 294 & 65.0 \\
4 & Poor & $91-130$ & 63 & 13.9 \\
5 & Very Poor & $50-90$ & 6 & 1.3 \\
\hline \multicolumn{2}{r}{ Total } & 452 & 100 \\
\hline
\end{tabular}


Table 4

Students' Technology Use Score Distribution

\begin{tabular}{rcccc}
\hline No & Categories & Interval & Total (f) & Percentage (\%) \\
\hline 1 & Very Good & $81-92$ & 13 & 2.9 \\
2 & Good & $67-80$ & 89 & 19.7 \\
3 & Fair & $52-66$ & 272 & 60.2 \\
4 & Poor & $38-51$ & 70 & 15.5 \\
5 & Very Poor & $23-37$ & 8 & 1.8 \\
\hline & Total & & 452 & 100 \\
\hline
\end{tabular}

other $19.7 \%$ of the students are into the good category and $2.9 \%$ of them are in the very good category. On the other hand, $15.5 \%$ of students are in the poor category and $1.8 \%$ of them are in the very poor category. These numbers imply that more students are able to use technology compared to the students who could not use technology. However, most of the students are still in the fair category.

The normality test is done preliminary in the analysis to look at the data distribution. It is meant to show whether particular data are normally distributed or not. In this study, normality test employed was Kolmogorov-Smirnov Normality test with accepted Normality. Table 5 indicates that the Language Learning Strategy has Sig. value 0.343 , Technology' Use has 0.095 and Writing has 0.055 . Those three variables have Sig. value above 0.05 , which indicates that they are all normally distributed data.

Students' language learning strategies are also related to their ability to perform language skills such as reading, listening, speaking and writing. In this study, the first hypothesis is to look for the relationship between students' language learning strategies and their writing abilities especially for students in Yogyakarta. This study discovers that Language Learning Strategies affect students' Writing Abilities as shown by R 0.282 with Sig. 0.000. It shows that Language Learning Strategies positively and significantly affects students' Writing Skills. The better the students' in using their strategies, the better they will be at writing.

The result of this study shows that there are positive and significant relationships between students' language learning strategies and writing skills. This finding is related to the study conducted by Mistar, Zuhairi, and Parlindungan (2014) who finds that students who employ strategies more have better writing abilities. Another finding has confirmed that language learning strategies improve students' writing abilities (Manham \& Nejadansari, 2012). These findings show that language learning strategies affect students' writing

Table 5

Language Learning Strategy, Technology Use, and Writing Normality Test

\begin{tabular}{lccc}
\hline Variable & Residual & Sig. & Interpretation \\
\hline Language Learning Strategy & 0.938 & 0.343 & Normal \\
Technology' Use & 1.235 & 0.095 & Normal \\
Writing & 1.341 & 0.055 & Normal \\
\hline
\end{tabular}


abilities. Other studies about students' language learning strategies found that students' strategies use correlated with their language learning skills (Setyiadi, 2016). In Setyadi's study, the finding suggested that different language skills required different strategies. Based on the study, the writing skills were highly correlated with students' use of metacognitive strategies rather than cognitive strategies. The finding further strengthens the finding of this study which shows that students' learning strategies contributes to their writing performance. Similarly, a study by Raoofi, Binandeh, and Rahmani (2017) suggested that students' high writing skills were indicated by their high strategy use.

However, a study indicating contrastive results was conducted by Chand (2014). The study aimed to find a relationship between language learning strategies preference to students' abilities in writing academically. The study employed SILL questionnaire to 88 undergraduate students and for the students' writing, internet software called Markin was employed to assess their writing. The findings of this study suggested that students' strategy use did not bring significant impacts in their writing performance (Murray, 2010). This study employed SILL to 66 students while also assessing their proficiency. The finding suggested that there was just little correlation between language learning strategy use with students' proficiency.

Students who effectively use language learning strategies are most of the time students' who perform better in the classroom. By applying strategies, students could control, direct, and manage themselves to be better at learning. This will help students when they are facing writing tasks. Students' strategies in writing could come in many forms ranging from cognitive strategies up to affective strategies. Cognitive strategies are known for strategies related to writing tasks (Oxford, 2011). Cognitive strategies are used by students to manage their plans or ideas before and while they are writing. When these strategies are applied, students become more aware of their organization of the ideas and how the ideas will be presented in their writing and thus students could write better. Other strategies such as social strategies are also useful when students need to communicate and discuss with their peers about the ideas, grammar, vocabularies, or text organization.

The students thus could work together to solve problems on the task given to them, so they could write better through collaboration with their partners. In addition, students who apply metacognitive strategies also become aware of their writing purposes, the features of the writing they need to apply or strategies they need to write more effectively. Using strategies, students might monitor their progress, using their surrounding resources as materials to learn English, explore more vocabulary, improving grammar understanding which in the end the efforts lead to the development of the writing skill (Griffiths, 2008). In other words, students who can use effective language learning strategies can improve their competences and regulate themselves for their successful learning.

Learning with Technology means teaching learning in the classroom in empowering technology to support and facilitate learning. Technology use in the classroom is derived into developing and creating a learning system that involves some technologies to enhance the teaching learning process (Blake, 2008). Technology now is such a familiar thing for students as they grow and live with it. Thus, if students carefully use technology, students can boost their learning. Moreover, the 
finding showing students' use of technology toward learning contributes to their writing skills is similar in her research of Blended Learning which shows that Blended Learning positively affects student's ability in writing. Implementation of Blended learning in the teaching learning enables students to be more flexible, motivated, oriented, and inspired. Blended learning which is famous for combining a traditional classroom with a technologyrich classroom means that purposefully and carefully implementation of technology in a classroom provides students with such benefits (Liu, 2013).

In the same manner, the availability of technology within the classroom greatly enhances the teaching learning process as in her classroom Blended Learning is employed and successfully boosts the teaching learning process (Sari, 2017). In addition, she emphasizes that through technology students have opportunities to share ideas, work with each other and apply numerous strategies so that they can work together on language issues. In other words, technology can be said to bridge students together and facilitate them together which leads to better language performances (Kost, 2011). Moreover, studied computer-cooperativeness influences in students' writing performance. This study implemented text-brainstorming, drawing and mind-mapping as the computer cooperative tools for the students. The findings of the study revealed that three computer cooperative tools help students improve their writing performance. These findings emphasize that when the students can use and have access to technology, their learning is enhanced (Lan, Sun, Cheng, \& Chang, 2015).

Through technology, students open a way for them to improve and maximize their learning that in the end it leads to a better teaching learning process as a whole and especially for learning a language. The more students get the opportunity to not only understand but also to use the available technology around them, the more they can optimize their learning. Further, the technology which is available for the students might help them gathering information about learning materials such as grammar, vocabulary, or text organization.

In the time the students gather the information, they might be storing it in their gadget or computer and when they need the information, they can easily re-learn from it. With current conditions where the internet is most accessible, students might also use online grammar checker or built-in grammar checker in their computer to help them assess their writing. Other possibilities where technology can help students improve their writing are when the students can easily exchange information or work collaboratively. This opportunity helps students build their ideas and understanding about the task they are doing. Furthermore, students might also more motivated and excited when they are learning with technology. Students who are high in motivation and excitements perform better in the classroom.

Language Learning Strategies which are effectively used and employed by students are such crucial requirements for them if they want to be successful at learning. Good language learners are usually associated with learners who use learning strategies in their learning. Language Learning strategies are defined as manageable, conscious, and devoted efforts students put to their learning so that they can learn a new language. Such synchronization of effective use of learning strategies and learning steps promotes successful teaching learning (Ferris, 
2012). Moreover, language learning strategies are not only prominent factors in the classroom, another factor such as students' technology use also might influence students' learning. Through technology, students now have access to much information and learning materials that comes in various kinds of forms such as video, text, picture, and audio. The availability of technology not only helps students find learning materials but also helps them manage them, to make it more interesting. Students will be more active and interested in teaching learning if they are given contributions to choose learnings materials they need to learn (Becker, Rodriguez, Estrada, Davis, 2016).

This study has shown that the correlation value of language learning strategies and the use of technology have a positive relationship with students' writing abilities. This finding suggest that learners who are great at writing are the ones who employ learning strategies as indicated in several studies confirming the positive effects of language learning strategies to students' writing abilities (Mistar et al., 2014).

Teaching learning should be altered and adapted to current changes for example language learning strategies available in the realm of advancing technology in the classroom. English especially is needed now as the emerging of technology and information is delivered in English (Mutlu \& Eroz-Tuga, 2013). Appropriate usage of technology in the classroom promotes improvements in students' learning. The findings above emphasize that technology should be promoted along with the use of appropriate language learning strategies in the classroom as they offer enormous benefits for students and their learning.

This study aimed to explore the relationship between language learning strategies and student use of technology toward their writing abilities. However, in this study, the researcher met some inevitable obstacles especially in students' available time to do the writing task. The schools allocated different periods for the researcher to collect the data as the teachers had their schedule and the students needed to prepare for the upcoming mid-term test. Some of them needed to catch up with the learning material thus the researcher just had a limited time to collect the data especially for the students' writing test. As a result, some students got the least amount of time possible to do the writing test. This condition might hinder the students to produce the best writing possible so that the score might not reflect the true nature of the students' writing competencies.

\section{CONCLUSION}

Language learning strategies have a significant and positive relationship with students' writing abilities. This research further proves that developing students' effective use of language learning strategies help them learn better at developing language skills. This finding provides further support to previous studies that show the contribution of language learning strategies to better language learning performance. This study proves that Technology Use has a significant and positive relationship with students' writing abilities. Students who use technology for their learning performs better in the classroom. This finding confirms that the availability of technology followed by students' use contributes to the teaching learning process in the classroom. Language learning strategies and technology use have a significant and positive relationship with students' writing abilities. Both language learning strategies and students' technology use can contribute to their performance in the classroom. 


\section{REFERENCES}

Adams, A., \& Brindley, S. (2007). Teaching secondary English with ICT. New York: Open Universtiy Press.

Ardasheva, Y., \& Tretter, T. R. (2013). Strategy inventory for language learning- ELL student form: Testing for factorial validity. The Modern Language Journal, 97(2), 474-489. Retrieved from http://www.jstor.org/ stable/43651650.

Becker, S. A., Rodriguez, J. C., Estrada, V., \& Davis, A. (2016). Innovating language education: An NMC Horizon Project strategic brief (pp. 1-24). The New Media Consortium.

Bikowski, D., \& Casal, J. E. (2018). Interactive digital textbooks and engagement: A learning strategies framework. Language Learning \& Technology, 22(1), 119-136. https:// doi:10125/44584.

Blake, R. J. (2013). Brave new digital classroom: Technology and foreign language learning. Washington, D.C: Georgetown University Press.

Chand, Z. A. (2014). Language learning strategy use and its impact on proficiency in academic writing of tertiary students. Procedia-Social and Behavioral Sciences, 118 , 511-521. https://doi: 10.1016/j. sbspro.2014.02.070.

Clayton, K., Blumberg, F., \& Auld, D. P. (2010). The relationship between motivation, learning strategies and choice of environment whether traditional or including an online component. British Journal of Educational Technology, 41(3), 349-364. doi:10.1 $111 / \mathrm{j} .1467-8535.2009 .00993$.

De Andrés Martínez, C. (2012). Developing metacognition at a distance: sharing students' learning strategies on a reflective blog. Computer Assisted
Language Learning, 25(2), 199-212.

De Silva, R. (2015). Writing strategy instruction: Its impact on writing in a second language for academic purposes. Language Teaching Research, 19(3), 301-323. https:// doi.org/10.1177/1362168814541738.

Drigas, A., \& Charami, F. (2014). ICTs in English learning and teaching. International Journal of Recent Contributions from Engineering, Science \& IT (iJES), 2(4), 4-10. http:// dx.doi.org/10.3991/ijes.v2i4.4016..

Egbert, J. O. Y. (2018). CALL (Computer Assisted Language Learning) Methodology. The TESOLEncyclopedia of English Language Teaching, 1-6. DOI: 10.1002/9781118784235.

Erben, T., Ban, R., \& Castaneda, M. (2009). Teaching English language learners through technology. New York: Routledge.

Ferris, D. R. (2012). Written corrective feedback in second language acquisition and writing studies. Language Teaching, 45(4), 446. doi:10.1017/ S0261444812000250.

Griffiths, C. (Ed.). (2008). Lessons from good language learners. New York: Cambridge University Press.

Kost, C. (2011). Investigating writing strategies and revision behavior in collaborative wiki projects. Calico Journal, 28(3), 606-620.

Lan, Y. J., Sung, Y. T., Cheng, C. C., \& Chang, K. E. (2015). Computersupported cooperative prewriting for enhancing young EFL learners' writing performance. Language Learning \& Technology, 19(2), 134-155. Retrieved from http://1lt.msu.edu/issues/ june2015/lansungchengchang.

Liu, M. (2013). Blended learning in a university EFL writing course: Description and evaluation. Journal of 
Language Teaching \& Research, 4(2). doi:10.4304/jltr.4.2.301-309.

Mahnam, L., \& Nejadansari, D. (2012). The effects of different pre-writing strategies on Iranian EFL writing Achievement. International Education Studies, 5(1), 154-160. http://dx.doi. org/10.5539/ies.v5n1p154.

Mistar, J., Zuhairi, A., \& Parlindungan, F. (2014). Strategies of learning English writing skill by Indonesian Senior High School Students. Arab World English Journal, 5(1).

Murray, B. (2010). Students' language learning strategy use and achievement in the Korean as a foreign language classroom. Foreign Language Annals, 43(4), 624-634.

Mutlu, A., \& Eroz-Tuga, B. (2013). The role of computer-assisted language learning (CALL) in promoting learner autonomy. Eurasian Journal of Educational Research, 51, 107-122.

Nakatani, Y. (2010). Identifying strategies that facilitate EFL learners' oral communication: A classroom study using multiple data collection procedures. The Modern Language Journal, 94(1), 116-136. https://doi.org/10.1111/j.15404781.2009.00987.x.

Oxford, R. L. (2008). Hero with a thousand faces: Learner autonomy, learning strategies and learning tactics in independent language learning. Language learning strategies in independent settings, 33, 41.

Oxford, R. L. (2016). Teaching and researching language learning strategies: Selfregulation in context. New York: Taylor \& Francis.

Oxford, R. L., \& Lin, C. Y. (2012). Autonomous learners in digital realms: Exploring strategies for effective digital language learning. Independent language learning: Building on experience, seeking new perspectives, 157171.

Oxford, R. L., Rubin, J., Chamot, A. U., Schramm, K., Lavine, R., Gunning, P., \& Nel, C. (2014). The learning strategy prism: Perspectives of learning strategy experts. System, 43, 30-49. http://dx.doi.org/10.1016/j. system.2014.02.004.

Rahimi, M., \& Katal, M. (2012). The role of metacognitive listening strategies awareness and podcast-use readiness in using podcasting for learning English as a foreign language. Computers in Human Behavior, 28(4), 1153-1161. https://doi.org/10.1016/j. chb.2012.01.025.

Raoofi, S., Binandeh, M., \& Rahmani, S. (2017). An investigation into writing strategies and writing proficiency of university students. Journal of Language Teaching and Research, 8(1), 191-198. http://dx.doi.org/10.17507/ jltr.0801.24.

Saks, K., \& Leijen, Ä. (2014). Distinguishing self-directed and selfregulated learning and measuring them in the e-learning context. Procedia-Social and Behavioral Sciences, 112, 190-198. doi: 10.1016/j. sbspro.2014.01.1155.

Sari, I. (2017). Improving students' vocabulary mastery by using blended learning model in state polytechnic Padang. Script Journal of Linguistics and English Teaching, 2(1), 101-110. http://dx.doi.org/10.24903/sj.v2i1.66.

Setiyadi, A. (2016). How successful learners employ learning strategies in an EFL setting in the Indonesian context. English Language Teaching, 9(8), 28-38. http://dx.doi.org/10.5539/ elt.v9n8p28. 
Su, Y. (2018). A review of language learning strategy research. Theory and Practice in Language Studies, 8(5), 522-527. http://dx.doi.org/10.17507/ tpls.0805.10.
Zeynali, S. (2012). Exploring the gender effect on EFL learners' learning strategies. Theory \& Practice in Language Studies, 2(8). http://doi.org/ 10.4304/tpls.2.8.1614-1620. 